\title{
Predictive value of clinical and laboratory findings in diagnosis of brucellosis
}

\section{Bruselloz tanısında klinik ve laboratuvar bulgularının tahmini değerleri}

\author{
Özgür Dağl1, Gül Durmuş \\ University of Health Sciences Bursa Yüksek İhtisas Research and Training Hospital Department of Infectious \\ Diseases and Clinical Microbiology, Bursa, Turkey
}

Geliş Tarihi: 19.05.2017 Kabul Tarihi: 02.10.2017

Doi: 10.21601/ortadogutipdergisi.315062

\begin{abstract}
Aim: Although the definitive diagnosis of brucellosis requires isolation of the Brucella species, diagnosis is usually made based on both clinical and laboratory findings. The aim of this study was to determine the minimum required parameters that could be valuable in the diagnosis of brucellosis.

Material and Method: A retrospective study was performed to compare the clinical and laboratory findings in 50 patients who were confirmed to have brucellosis by cultures with 50 patients with fever. Features independently predictive of brucellosis were assessed by multivariate logistic regression. Sensitivity, specificity and positive and negative predictive values were estimated.

Results: Significant clinical features of brucellosis were hepatomegaly, splenomegaly, arthritis, RF positivity, leucopenia, thrombocytopenia, anemia, and elevated ALT levels. Five of these features were found to be predictive for the diagnosis of brucellosis; splenomegaly, arthritis, RF positivity, thrombocytopenia and elevated ALT levels.

Conclusion: For the diagnosis of brucellosis, serum aglutination test does not have high specificity and sensitivity and waiting the results of cultures will delay the proper treatment. Predictive value of these results are worth taking into consideration in endemic regions.
\end{abstract}

Keywords: Brucellosis, diagnosis, prediction

\section{Öz}

Amaç: Brusellozun kesin tanısı bakterinin izolasyonu ile konsa da çoğunlukla klinik ve laboratuvar bulgulara dayanır. Bu çalışmanın amacı bruselloz'un tanısında gereken parametreleri ve tahmin değerlerini araştırmaktır.

Gereç ve Yöntem: Kültürde izole ederek tanı konan 50 bruselloz hastasının klinik ve laboratuvar bulguları ile klinikte ateş nedeni ile yatırılmış 50 hastanın bulguları retrospektif olarak taranarak karşılaştırıldı. Bu veriler lojistik regresyon analizi ile değerlendirildi. Sensitivite, spesifisite, pozitif ve negatif prediktif değerler hesaplandı.

Sonuçlar: Brusellozun anlamlı klinik özellikleri; hepatomegali, splenomegali, artrit, RF pozitifliği, lökopeni, trombositopeni, anemi ve artmış ALT seviyeleri olarak saptandı. Bu özelliklerden ise splenomegali, artrit, RF pozitifliği, trombositopeni ve artmış ALT seviyelerinin Bruselloz'un tanısında anlamlı tahmin değerlerine sahip olduğu tespit edildi.

Yorum: Bruselloz'un tanısında serum aglütinasyon testlerinin yeterli, yüksek düzeyde spesifisite ve sensitivite değerleri bulunmamakta, kültür sonuçlarının beklenmesi de tedaviyi geciktirebilmektedir. Bu nedenle endemik bölgelerde bruselloz tanısı için bu sonuçların tahmini tanısal değerleri göz önünde bulundurulmalıdır.

Anahtar Kelimeler: Bruselloz, teşhis, tahmin 


\section{Introduction}

Brucellosis is a primary zoonotic infection caused by Brucella spp., a Gram negative bacteria, and is transmissible to humans through direct contact with infected animals, consumption of dairy products, or inhalation of aerosols. Brucellosis is a multisystem disease that shows wide clinical polymorphism. Its main clinical manifestations are fever, arthritis and hepatomegaly. Focal infections include osteomyelitis (particularly sacrolitis), splenomegaly, epididymitis, endocarditis, meningitis, meningoencephalitis, and myeloradiculopathy. Also diffuse maculopapular rash is rarely seen in some cases. It may progress as subclinical, acute, subacute or chronic infection [1-3].

Brucellosis is diagnosed by isolation brucella from blood, bone marrow, or tissue or by serology; however the polymerase chain reaction (PCR) assay is only available in a few laboratories. Serology includes tests for agglutinating antibodies. In addition, cultures can be negative when patients undergo antibiotic therapy prior to diagnosis [4]. Diagnosis of brucellosis requires assessment of medical history, clinical evaluation, and routine laboratory and radiologic tests combined with culture, serology, or PCR assay [5]. Routine laboratory tests include complete blood count, erythrocyte sedimentation rate, C-reactive protein, and liver function tests; however, they are not specific for the diagnosis, and wide patient variability is known to exist [6]. Blood and bone marrow are the most suitable specimens used in the isolation of brucella. In patients receiving antibiotics, as well as in patients with a chronic form of brucellosis, bone marrow culture appears more sensitive [7]. Numerous serologic methods are used in the diagnosis of brucellosis. Although serum agglutination test (SAT) is usually recognized as the reference technique, it is labor-intensive and time-consuming. Thus, Rose-Bengal slide agglutination test (RBT), which uses stained killed B. abortus bacterial cells, offers a simple and affordable card test. Negative serology does not exclude the diagnosis in brucellosis [8]. In addition, brucella antibodies can persist long after the patient's recovery, and thus it is not always possible to distinguish patients with active disease from those with past infection [9]. Therefore the aim of this study was to find out the minimum required laboratory and clinical parameters that can be used in the early diagnosis of brucellosis.

\section{Material and Method}

This retrospective study was performed at the Kilis State Hospital, Gaziantep 25 Aralık State Hospital and Bursa Yuksek Ihtisas Research and Training Hospital from Turkey between 2007 and 2015. Institutional review board approval was taken for the analysis of previous data. Patients with an initial diagnosis of brucellosis were selected from those admitted to the clinic with signs of fever $\geq 38.0^{\circ} \mathrm{C}$ for $>4$ days approximately and at least one of the following clinical signs: hepatomegaly, splenomegaly, arthritis, rheumatoid factor (RF) positivity, leucopenia, thrombocytopenia, anemia and elevated ALT levels. Blood cultures were collected from the all patients during the fever period. Patients with

Positive blood cultures for Brucella spp. were included in Group 1 as brucellosis fever patients. Patients were investigated for fever etiology when Brucella spp. was not detected in blood cultures or other body fluids and were included in Group 2 as non-brucellosis fever patients. Hepatomegaly, splenomegaly, arthritis were clinically evaluated and laboratory RF positivity, leucopenia, thrombocytopenia, anemia and alanine amino transferase, brucella serum agglutination titer findings were recorded and compared between the two groups. Patients with a diagnosis of non-brucellosis fever which could not be confirmed by the microbiological methods and patients with different severity of clinical, laboratory findings were excluded from the study group. Group 1 had 50 patients with brucellosis and their diagnoses were confirmed by the isolation of Brucella spp. in the blood. There were 27 males and 23 females with a mean age of $29.7 \pm 10.1$ years. Group 2 had 50 patients with diagnoses of other infections. There were 25 males and 25 females with a mean age of $29.6 \pm 13.4$ years. Blood cultures were performed using BACTEC (Becton, Dickinson USA) or BacT Alert 3D(France) automatized blood culture systems. The culture tubes in which some colonies were observed were centrifuged at $3000 \mathrm{rpm}$ for three to five minutes. After the centrifugation, subculture was performed into blood and EMB agar. Positive colonies were biochemically identified by Vitek 32 Biomeriux automized system (France). Independent samples- $t$ and $x 2$ tests were used to compare the clinical and laboratory parameters of the groups. Logistic regression analysis was performed to evaluate correlation of the variables with brucellosis. 


\section{Results}

In the blood culture of 50 brucellosis patients, B. melitensis was isolated in 33 patients, and B. abortus was isolated in 17 patients. The final diagnosis of non-brucellosis fever patients were salmonellosis, pneumonia, urinary tract infection and staphylococcal infection. When the clinical parameters of the groups were compared, there was a significant difference between the groups regarding hepatomegaly, splenomegaly, arthritis, RF positivity, leucopenia, thrombocytopenia, anemia and elevated ALT levels. (Table 1). Sensitivity, specificity, and positive predictive value (PPV) and negative predictive value (NPV) are shown in Table 2. When splenomegaly, RF positivity, arthritis, a serum agglutination titer of $1 / 80$, normal leukocyte count $(<10800 / \mathrm{mm} 3)$ coexisted in patient with fever, PPV was $52.8 \%$, and the diagnosis was definitely brucellosis. The sensitivity and specificity of detection of these findings in the diagnosis of brucellosis were $100 \%$ and $10.6 \%$ respectively.

Table 1. Clinical and laboratory findings among patients with culture proven brucellosis and patients with non-brucellosis fever

\begin{tabular}{|l|c|c|c|c|}
\hline Parameters & $\begin{array}{c}\text { BFP } \\
\text { n:50 }(\%)\end{array}$ & $\begin{array}{c}\text { NBFP } \\
\text { n: } 50(\%)\end{array}$ & P & OR (95\% CI) \\
\hline Gender M/F & $27 / 23$ & $25 / 25$ & 0.385 & 1.06 \\
\hline Hepatomegaly & $35(70)$ & $30(60.0)$ & 0.042 & 2.28 \\
\hline Splenomegaly & $30(60)$ & $20(40.0)$ & 0.005 & 2.79 \\
\hline Arthritis & $38(76.0)$ & $14(28.0)$ & 0.000 & 10.24 \\
\hline RF positivity & $22(44.0)$ & $14(28.0)$ & 0.02 & 2.37 \\
\hline Pharingytis & $31(62.0)$ & $30(60.0)$ & 0.200 & 1.59 \\
\hline Anemia $(<13$ g/dl) & $23(46)$ & $24(48)$ & 0.54 & 1.25 \\
\hline Leucopenia $<4300 / \mathrm{mm} 3)$ & $26(52.0)$ & $16(32.0)$ & 0.005 & 3.01 \\
\hline Trombocytopenia $(<130.000 / \mathrm{mm} 3)$ & $36(72.0)$ & $20(40.0)$ & 0.000 & 5.19 \\
\hline Eosinopenia $(0-1 \%)$ & $40(80)$ & $30(60.0)$ & 0.000 & 4.01 \\
\hline ALT $(>45$ U/L) & $35(70)$ & $26(52.0)$ & 0.004 & 2.86 \\
\hline AST $(>45$ U/L) & $23(46.0)$ & $28(56)$ & 0.83 & 0.93 \\
\hline LDH $(>500 \mathrm{U} / \mathrm{L})$ & $26(52.0)$ & $30(60.0)$ & 0.859 & 1,06 \\
\hline CRP $(>20)$ & $30(60.0)$ & $28(56.0)$ & 0.139 & 1.73 \\
\hline BFP: Brucellosis fever patients, NBFP: Non-brucellosis fever patients, CI: Confidence interval, n: Number of the patients, \%: Percentage
\end{tabular}

BFP: Brucellosis fever patients, NBFP: Non-brucellosis fever patients, CI: Confidence interval, n: Number of the patients, \%: Percentage

Table 2. Sensitivity, specificity and predictive values (\%) of combined clinical and laboratory findings in patients $(95 \%$ CI, $\mathrm{p}=0.002)$

\begin{tabular}{|l|l|l|l|l|}
\hline & Sensitivitiy & Specificity & $\begin{array}{l}\text { + Predic- } \\
\text { tive value }\end{array}$ & $\begin{array}{l}\text {-Predictive } \\
\text { value }\end{array}$ \\
\hline SM + RF & $77.6 \%$ & $47.5 \%$ & $61.1 \%$ & $31.3 \%$ \\
\hline SM + RF + ART & $90.5 \%$ & $33.2 \%$ & $58.7 \%$ & $20.2 \%$ \\
\hline SM + RF + SAT 1/40 & $95.9 \%$ & $23.8 \%$ & $54.7 \%$ & $12.3 \%$ \\
\hline SM + RF + SAT 1/80 & $82.9 \%$ & $36.7 \%$ & $57.9 \%$ & $30.4 \%$ \\
\hline SM + RF + ART + SAT 1/80 & $95.3 \%$ & $25.5 \%$ & $57.3 \%$ & $10.9 \%$ \\
\hline SM + RF + ART + SAT 1/80 + L <10.800 & $100 \%$ & $10.6 \%$ & $52.8 \%$ & $0.0 \%$ \\
\hline SM + RF + ART + SAT 1/ART + SAT 1/80 + L <4300 & $95.6 \%$ & $19.6 \%$ & $54.6 \%$ & $13.9 \%$ \\
\hline $\begin{array}{l}\text { SM: Splenomegaly, RF: Rheumatoid Factor +, ART: Arthritis, SAT: Brucella serum aglutination titer, L: leucocyte count/mm3, } \\
\text { CI:confidence interval, \%: Percentage }\end{array}$ \\
\hline
\end{tabular}


When splenomegaly, RF positivity, arthritis, a serum agglutination titer of $1 / 80$, and leucopenia $(<4300 /$ $\mathrm{mm} 3$ ) coexisted in patient with fever, PPV was $54,6 \%$, NPV was $13.9 \%$, sensitivity was $95.6 \%$ and specificity was $19.6 \%$. Logistic regression analysis revealed that splenomegaly, arthritis, RF positivity, thrombocytopenia and elevated ALT level were found as independent risk factors in the diagnosis of the brucellosis. Independent risk factors increase the probability of the patient having brucellosis (Table 3). According to the data we obtained in patients with fever, the probability of brucellosis with splenomegaly was 8.13 fold more than that of brucellosis without splenomegaly. The probability of brucellosis in the patients with arthritis was 16.59 fold more than those without arthritis. The probability of brucellosis in the patients with RF positivity was 4.86 more than those without RF positivity. The probability of brucellosis in the patients with thrombocytopenia was 7.87 fold more than those without thrombocytopenia. It was detected that if brucella serum agglutination titration increases, the probability of brucellosis will increase (Table 4).

Table 3. Logistic regression analysis, predictor variables for brucellosis cases

\begin{tabular}{|l|c|c|}
\hline Predictor variables & $\mathrm{P}$ & OR (95\% CI) \\
\hline Splenomegaly & 0.004 & 8.13 \\
\hline Arthritis & 0.000 & 16.59 \\
\hline Trombocytopenia & 0.005 & 7.87 \\
\hline RF+ & 0.024 & 4.86 \\
\hline Elevated ALT level & 0.003 & 5.3 \\
\hline CI: confidence interval, OR: odds ratio \\
\hline
\end{tabular}

Table 4. Distribution of brucella serum aglutination titers in patients

\begin{tabular}{|l|c|c|}
\hline SAT titers & BFP & NBFP \\
\hline Negative & $14(28.0)$ & $22(44.0)$ \\
\hline $1 / 20$ & $7(14.0)$ & $10(20.0)$ \\
\hline $1 / 40$ & $12(24.0)$ & $12(24.0)$ \\
\hline $1 / 80$ & $7(14.0)$ & $5(10.0)$ \\
\hline $1 / 160$ & $14(28.0)$ & $0(0)$ \\
\hline
\end{tabular}

BFP: Brucellosis fever patients, NBFP: Non-brucellosis fever patients, $\mathrm{p}=0.002, \mathrm{x} 2=9.36$

\section{Discussion}

Brucellosis is a major public health problem in Southeastern Turkey and many other areas in the developing countries. The most definitive diagnosis is achieved by isolating
Brucella spp. from blood or bone marrow [10]. However microbiological documentation may not be done routinely and a certain time interval is required for identification. Moreover, because of prior antibiotic therapy bacterial isolation rate is low. Other infections such as salmonellosis may initially be confused with brucellosis [11].But, isolation of the bacterium is not awaited to initiate the treatment for brucellosis due to long duration, multisystem involvement and the frequency of complications [12]. No laboratory and clinical finding with higher sensitivity and specificity has been defined apart from bacterial isolation as it is true for many infectious diseases as well [8-9-13]. Of note, standard serologic testing does not detect the rare human cases of B. canis because of antigenic differences [14]. A wide spectrum of laboratory abnormalities related to the hematologic system in brucellosis is reported. Anemia, leukopenia, leukocytosis, thrombocytopenia, thrombocytosis, and pancytopenia are relatively common [15]. Hypersplenism due to brucellosis may add to the severity of hematologic complication. Bone marrow involvement shows hyper cellularity, hemophagocytosis, and granulomas [16]. In previous studies it was reported that arthritis was quite commonly observed in patients with brucellosis [17]. Liver involvement of brucellosis was also reported before which explains the elevated ALT levels as it was observed in our study as well [18]. In our study, splenomegaly, arthritis, RF positivity, thrombocytopenia and elevated ALT levels were found to have a predictive value for brucellosis. In a study with similar observations and working plan performed in the same region splenomegaly, relative bradycardia, rose spots, thrombocytopenia and elevated AST level were found to be predictive for the diagnosis of salmonellosis which is also endemic and difficult to be isolated easily [19]. Therefore this previous observations about salmonellosis also concentrated us about another study about brucellosis from the same perspective resulting in some different findings. As a result in endemic regions, the diagnosis of brucellosis can be made prior to microbiological test results when these findings are present in the first $24 \mathrm{~h}$ of hospitalization. In addition, splenomegaly, RF positivity, arthritis, a serum agglutination titer of $1 / 80$, normal leukocyte count $(<10800 / \mathrm{mm} 3)$ or leucopenia $(<4300 /$ $\mathrm{mm} 3$ ) in patient with fever have a high sensitivity in the diagnosis of brucellosis. 
In conclusion, clinical and laboratory findings can help the clinician to diagnose brucellosis in the absence of microbiological confirmation. For the diagnosis of brucellosis, waiting the results of cultures will delay the proper treatment. Therefore, predictive value of these results are worth taking into consideration in endemic regions to start an empiric antibiotic treatment

for preventing complications.

\section{Declaration of conflicting interests}

The author declared no conflicts of interest with respect to the authorship and/or publication of this article.

\section{References}

1. Young EJ. Brucella species. In:Mandell GL, Benett JE, Dolin R, eds. Mandell, Douglas, and Bennett's Principles and Practice of Infectious Disaeses. 6th ed. Philadelphia: Churchill Livingstone 2005;2669-74.

2. Tekin R, Karakoç ZC, Demirpençe O, Retrospective analysis of 286 Brucellosis cases in the southeast of Turkey. J Clinic Exp Inv 2012;3:335-9.

3. Tursun S, Tas MA. A case of brucellosis presenting with diffuse maculopapular rash. Ortadogu Med J 2017;9:42-4.

4. Bosilkovski M, Dimzova M, and Grozdanovski K. Natural history of brucellosis in an endemic region in different time periods. Acta Clin Croat 2009;48:41-46.

5. Lindquist D, Chu M, and Propert W In Murray P, Baron E, and Jorgensen J, eds. Manual of Clinical Microbiology, 9th ed. Washington DC:ASM Press 2007;824.

6. Franco MP, Mulder M, Gilman RH. Human brucellosis. Lancet Infect Dis 2007;7:775-86.

7. Bosilkovski M, Krteva L, Dimzova M. Human brucellosis in Macedonia 10 years of clinical experience in endemic region. Croat Med J 2010;51:327-36.

8. Ulu-Kilic A, Metan G, and Alp E Clinical presentations and diagnosis of brucellosis. Recent Pat Antiinfect Drug Discov $2013 ; 8: 34$.
9. Gomez MC, Nieto JA, Rosa C, Evaluation of seven tests for diagnosis of human brucellosis in an area where the disease is endemic. Clin Vaccine Immunol 2008;15:1031-3.

10. Ertem M, Kurekci AE, Aysev D, Brucellosis transmitted by bone marrow transplantation. Bone Marrow Transplant 2000;26:225-6.

11. Bosilkovski M, Krteva L, Dimzova M. Brucellosis in 418 patients from the Balkan Peninsula: exposure-related differences in clinical manifestations, laboratory test results, and therapy outcome. Int J Infect 2007;11:342-7.

12. Solera J. Update on brucellosis: therapeutic challenges.Int Antimicrob Agents 2010;36:18-20.

13. Asaad AM, Alqahtani JM. Serological and molecular diagnosis of human brucellosis in Najran, Southwestern Saudi Arabia. J Infect Public Health 2012;5:189-94.

14. Mantecon Mde L, Gutierrez MP, Zarzosa Mdel P. Influence of brucellosis history on serological diagnosis and evolution of patients with acute brucellosis. J Infect 2008;57:397- 403.

15. Weil Y, Mattan Y, Liebergall M. Clin Infect Dis 2003; 36: 81-6.

16. Demir C, Karahocagil MK, Esen R, et al. Bone marrow biopsy findings in brucellosis patients with hematologic abnormalities. Chin Med J (Engl) 2012;125:1871-6.

17. Basappa G. Mantur, Mallanagouda S. Biradar, Rajendra C. Protean clinical manifestations and diagnostic challenges of human brucellosis in adults: 16 years' experience in an endemic area J of Med Microbiol 2006;55:897-903.

18. Ozturk-Engin D, Erdem H, Gencer S. Liver involvement in patients with brucellosis: results of the Marmara study. Eur J Clin Microbiol Infect Dis 2014;33:1253-62.

19. Kuvandik C, Karaoglan I, Namiduru M, Baydar I. Predictive value of clinical and laboratory findings in the diagnosis of enteric fever New Microbiologica 2009;32:25-30.

Corresponding Author: Özgür Dağlı, University of Health Sciences, Bursa Yüksek İhtisas Resarch and Training Hospital, Department Of Infectious Disesases and Clinical Microbiology, Emniyet Street, 16130, Yildırı / Bursa / Turkey

Email: drozgurdagli@yahoo.com 